\title{
A 'CULTURE OF CONSERVATISM': HOW AND WHY AFRICAN UNION MEMBER STATES OBSTRUCT THE DEEPENING OF THE INTEGRATION
}

\author{
Martin Welz \\ University of Konstanz, Germany
}

\section{Abstract}

This article explores the relations between the African Union and its member states. While there are improvements on the AU level with regard to the implementation of the African Peace and Security Architecture and the building of other institutions such as the Pan-African Parliament, it becomes apparent at the same time that on the state level governments are reluctant to engage in a deepening of the continental integration. Some countries even topple the integration process or undermine their own initiatives such as the African Peer Review Mechanism. This article examines this phenomenon, and labels the identified unwillingness to change the status quo a 'culture of conservatism'. Four explanations are offered for such a 'culture of conservatism': lack of capacity, unwillingness to surrender sovereignty, national leaders' reluctance to cede power, and the greater importance of regional economic communities as compared to the $\mathrm{AU}$.

\section{Introduction}

Officially launched in 2002, the African Union (AU) is still a young organisation. While it has made some progress, for example, with regard to the implementation of the African Peace and Security Architecture (APSA), the organisation lags behind its ambitions of political, economic and social integration. The establishment of the African Economic Community, for instance, originally envisaged for 2023 by the Abuja Treaty of 1991, is far behind schedule. Similarly, the establishment of 
African Regional Stand-by Brigades has been constantly deferred in several regions. It seems that the majority of African states does not want the continental integration project to gather further momentum, but wants to maintain the status quo - at least in several policy realms. As a result, a 'culture of conservatism' has emerged and the AU will remain an intergovernmental organisation in the foreseeable future, by and large dependent upon the will of its members, who shape and shove the organisation and sometimes even undermine it. In its current shape, the $A U$ is far removed from Kwame Nkrumah's (and later on Muammar al-Gaddafi's) vision of a United States of Africa.

The reasons for the 'culture of conservatism' and the AU member states' general reluctance to engage in the deepening of continental integration are various. They include an unwillingness to cede sovereignty, an unwillingness of national leaders to give up personal power, a lack of capacities and resources, as well as the fact that regional economic communities, which are developed simultaneously at the sub-regional level, are often more beneficial for its member states than the AU.

\section{The Status Quo in a Nutshell}

The AU has come a long way since the foundation of its predecessor, the Organisation of African Unity (OAU), in 1963. While the OAU was a loose alliance of states that strictly adhered to the principles of sovereignty and non-interference, the AU has since its formal launch in 2002 developed into a stronger institutionalised and diversified structure. This includes a relatively strong Commission, a Pan-African Parliament (PAP) with consultative functions, and several institutions which promote peace and security. Particularly the well-advanced security architecture, comprising the Peace and Security Council, the Continental Early Warning System, the regional Stand-by Brigades, ${ }^{1)}$ and the Panel of the Wise, leaves observers with the impression that some progress has been made (Packer and Rukare 2002: 365-379; Ankomah 2007: 10-12; Makinda and Okumu 2008; Akokpari 2008: 85112; Williams 2007: 253-279; Franke 2009; Engel and Porto 2010; Franke 2010: 179-200). Beyond that, the African Peer Review Mechanism (APRM), a monitoring process that looks inter alia into the political and socio-economic developments of voluntarily participating states, has been introduced and implemented in several African coun- 
tries. The South African based Business Day praised the AU in its early days for "present[ing] an opportunity for the continent to shrug off the interlude of denigration that some believe should be the continent's eternal fate" (Business Day, 16 August 2002). Generally speaking, there had been high hopes in Africa and beyond that the continent would move towards peace, stability, and socio-economic development after the AU superseded the OAU.

Contrary to the OAU, a strident defender of national sovereignty and the principle of non-interference in other states' internal affairs, Article 4(h) of the AU's Constitutive Act allows for

the right of the Union to intervene in a Member State pursuant to a decision of the Assembly in respect of grave circumstances, namely: war crimes, genocide and crimes against humanity as well as a serious threat to legitimate order to restore peace and stability to the Member State of the Union upon the recommendation of the Peace and Security Council (African Union 2000).

As a result of this reorientation, the $A U$ sent peacekeeping missions to Burundi (2003), Darfur (2005), Somalia (2007), the Comoros (2008), and most recently to Mali (2013) and the Central African Republic (2013). Furthermore, the AU adopted a policy to condemn any unconstitutional change of government by automatically suspending the country from the $A U$, indicating that non-interference is no longer sacrosanct. As a consequence, the Central African Republic, Egypt, Guinea-Bissau, Madagascar, Mali, and Niger have been suspended in the past after coups in these countries. The AU also takes a strong position on political violence. A recent example is when the AU Peace and Security Council turned against one of the AU's main sponsors, Libya's former head of state Gaddafi, during the early phase of Libya's transition process in 2011, and condemned his regime's and the opposition's violence (African Union Peace and Security Council 2011). Yet, it is also true that the AU's approach is not coherent. For instance, as discussed in more detail below, the AU did not address the crisis in Zimbabwe in a sustainable manner.

The APSA is only one frontline. The list of further challenges is long and includes a democratic deficit, lack of respect for human rights, rule of law, economic decline, brain drain, poverty, starvation, marginalisation, poor infrastructure, and the persistent weakness of African states (Herbst 2000; Cilliers 2003; Murithi 2005; Makinda and 
Okumu 2008; Akokpari 2008). Some of these challenges have already been addressed by the $A U$ and some progress has been made. However, no one can expect that these deep-rooted problems can be solved within days, weeks, months, or even years. Most of the problems are structural and it will take decades to overcome them. Consequently, the yardstick for measuring the success of the AU must not be the outcome of the AU policies but the approach the organisation takes in tackling these challenges. The analysis must therefore focus on the coherence, commitment and determination of the AU and its member states. Only then can a balanced and fair judgment of the organisation be provided.

\section{The gap between the $A U$ and its member states}

The following examination of the PAP, the APRM, and the proposed Union Government for Africa helps to reveal the divergent interests of the $A U$ and its member states that open a gap between the organisation's ambitions and policies on the one hand, and its member states' individual interests and policies on the other hand. Moreover, the AU policy of fighting unconstitutional change of government and its attempts to establish a viable peace and security architecture are scrutinised. The presented empirical material sheds some light on how earnestly the AU member states work within the AU framework.

The PAP is currently an advisory organ of the AU and is in theory designed to become the legislative arm of the organisation. In 2001, African leaders adopted a protocol noting that the PAP "shall [...] evolve into an institution with full legislative powers, whose members are elected by universal adult suffrage" (Organisation of African Unity 2001). Yet the PAP is far from this stage. Currently each member state has five delegates in the parliament, which is based in Midrand, South Africa. The parliamentarians are not elected by popular vote, but sent by national institutions - mostly national parliaments without direct approval of the electorate.

One might therefore assume that the parliamentarians are loyal to their national governments. Hence it might come as a surprise that the PAP is rather vocal and critical, particularly through its election observer missions in several African countries. The report on Zimbabwe's 2008 election, for instance, aptly "concluded that the atmosphere pre- 
vailing in the country, at the time [of the elections], did not give rise to the conduct of free, fair and credible elections" (Pan-African Parliament Election Observer Mission 2008). Other reports were similarly critical, such as the one on the Kenyan elections in 2007, which were followed by political unrest (Pan-African Parliament Election Observer Mission 2007). The parliament's plenary sessions are also often critical towards prevailing conditions in Africa. Parliamentarians "flexed their muscle" and passed resolutions calling, for instance, upon the Sudanese government to fully cooperate with the AU and to stop fighting in the Sudanese region of Darfur (Cilliers and Mashele 2004: 7382). Yet parliamentarians are aware that their work changes little, because the impact of the PAP is limited. With its two sessions per year, it can raise its voice. Yet, despite its role as consultative organ, the resolutions of the parliament on important topics, such as the formation of the United States of Africa and a Union Government for Africa (Pan-African Parliament 2007), frequently find no resonance by the AU Assembly and other AU decision making bodies.

Instead of supporting the PAP, the AU member states agreed to cut the parliament's budget by 22 per cent in 2009, making it more difficult for the parliament to fulfil its tasks. Officials in the AU headquarters link the budget cut to the parliament's critical work. They argue that the budget cut should be interpreted as an 'incentive' for the PAP to review its work. ${ }^{2)}$ There are reasons to assume that some national leaders were not pleased with the reports from the observer missions in particular, neither with the work and discussions of the parliament in general, including the latter's critique on the status of democracy, human rights, as well as the rule of law. One indication for this is that the PAP election observer missions have been merged with election observer missions of other AU organs. This was officially based on the argument of efficiency.

Given its financial constraints, its narrow confines, and its members' appointments instead of elections, the PAP will face obstacles to its further development. Abrahams Peter, a member of PAP, asked during a plenary session: "How will you become legislative with feeble feet?" (Pan-African Parliament 2010). One might argue that African leaders never wanted the Parliament to turn into a legislative arm. Had this been the case, key African states, such as Nigeria and South Africa, would have attempted to get another distribution of seats in their favour, instead of allocating five seats to each AU member state, 
which does not take country size, population, and financial contribution to the $\mathrm{AU}$ into account.

An analysis of the APRM comes to a similar conclusion. The fact that there is a monitoring mechanism that oversees democratic and socio-economic development is remarkable; yet, as mentioned above, the yardstick shall be the consistency and earnestness of the process itself, and in this regard there is room for improvement (South African Institute of International Affairs 2006; APRM Monitor 2006; Jordaan 2006; Herbert and Gruzd 2008, Natielsé 2009; Boumghar 2009). So the questions arise as to whether the signatory states of the APRM really want to be monitored and as to whether they will accept the critique they receive and implement the proposed plan of action.

The APRM Forum, the highest committee of the APRM initiative, used to be chaired by Meles Zenawi, Ethiopia's then Prime Minister, before Liberia's President Ellen Johnson Sirleaf took over, following Meles' death. During his time, Ethiopia was only ranked as 'partly free' (Freedom House Index 2008). Meles did not have a clean record in terms of good governance and democracy. Ethiopia's government silenced domestic opposition in 2001 (Africa Research Bulletin 2001) and in the aftermath of the 2005 and 2008 elections (Tronvoll 2009: 449-474). During the 2010 elections there was also reportedly fraud (European Union 2010). How can a leader with such credentials chair an institution that wants to see democracy and good governance flourish? With the election of Liberia's President and Nobel Peace Prize laureate Ellen Johnson Sirleaf as new APRM chairperson in May 2013, there are hopes that she might lend more legitimacy and earnestness to the review process. Yet the problem remains that African leaders review and discuss the final reports among themselves before publication, with some of them turning a blind eye to shortcomings in other countries because they expect similar treatment.

Several APRM member states have tried to influence their APRM report. The Mbeki-administration of South Africa, for example, appears to have been dissatisfied with the draft report and tried to whitewash it before publication (Mail and Guardian 2007). A draft that was discussed during a national conference on the APRM was later "considerably revised and downscaled, with many specific recommendations removed without explanation" (Herbert and Gruzd 2008: 264). The South African Institute of International Affairs compiled a 60-page comparison between the draft discussed at the national conference 
and the edited report, which was later submitted to the APRM Secretariat (South African Institute of International Affairs 2006). The editing seems to have been carefully conducted in order to ensure that South Africa was depicted as a model democratic state.

The subsequent draft of the report was leaked to the press, and the Sunday Times published an article which summarised the key points of the report, highlighting in particular the warnings on crime, poverty, unemployment, and the political domination of the African National Congress (ANC). The report considered these issues as a threat to the stability of South Africa's democracy (Sunday Times, 3 December 2006). If the version of the APRM report leaked by the Sunday Times was correct, then there have been substantial changes to the final report that was published in mid-2007. While crime and the ANC's dominance were initially defined as threats to South Africa's democracy, the final version of the report only sees crime as the key challenge (APRM 2007). The final report also does not indicate that the ANC's dominance is a threat to democracy, but reads: "As the dominant political party, the ANC has a specific responsibility to adopt an orientation and put in place the necessary political machinery that will nurture citizens capable of sustaining democracy and political governance through bottom-up decision-making processes" (APRM 2007). The APRM Monitor, a periodical that regularly reports on the APRM process, noted that, "several key issues had been downplayed or omitted" (APRM Monitor 2006). Effectively, with this manoeuvre President Mbeki and his administration undermined the president's own initiative, as Mbeki is widely considered to be one of the prime architects of New Partnership for Africa's Development (NEPAD) and also the APRM (Olivier 2003: 827).

There are more setbacks to mention: Mauritius, considered as one of the model democratic states in Africa, failed to complete its report in its first attempt, as it did not take the initiative seriously enough and did not comply with APRM standards, making a second try necessary (Herbert and Gruzd 2008: 243-254; Masterson 2005). Botswana and Namibia, considered, like Mauritius, to be model democratic states, have not even signed up for the process and show no intention to do so, while Rwanda has been accused of being "inadequately self-critical" in the process after subscribing to it (Jordaan 2006: 333-351).

It appears as if the review process has lost momentum. Be- 
tween 2003 and 2005, 23 states joined the review process, between 2006 and 2009 only seven states decided to participate in the review, and since 2010 only four states joined. Equatorial Guinea became the 34th and so far last participant, welcomed by the APRM Forum in January 2014. Equatorial Guinea's membership means that by now 62 per cent of African countries are part of the process. Only 17 countries, that is, 31 per cent of African countries, have completed the review process.

Despite these setbacks there are a few rather well conducted reviews that deserve some credit for a fairly candid and critical assessment. The reports on Uganda, for instance, go so far as to highlight that the country "is in danger of slipping back into a period of neopatrimonial rule [...] Having rescued Uganda from the Amin and Obote strangleholds, the current leadership should be concerned about its own legacy" (APRM 2009; APRM 2009b: xxix). Other challenges to Uganda's democratic development, however, are omitted in the report.

The APRM has further shortcomings. The plans of action, which should follow the recommendation of the review report, are not thoroughly implemented, as the cases of Algeria, Burkina Faso, and Uganda suggest. This raises doubts about the effectiveness of the mechanism and its long-term effects. Moreover, the cases mentioned above create serious doubts whether Africa's leadership wants to be thoroughly monitored. There seems to be a reluctance to implement the APRM's main idea of engaging in a transparent and open public dialogue about national political, social and economic circumstances, although many African leaders formally subscribed to it when they established the APRM and voluntarily joined it. The APRM remains a top-down process with African leaders excluding the public during the final stage of the discussions.

The so-called Grand Debate on the establishment of the United States of Africa and the building of a Union Government for Africa as an intermediate step sheds further light on the top-down approach. During this debate only a few attempts were made to find grassroots support for the idea and no national dialogues on this plan have been initiated. The debate also revealed a rift between the Union Government vision, vigorously pushed by a few states, and the vast majority of member states that aimed to prevent Gaddafi's dream of a united Africa under his leadership to become reality. Notwithstanding, the plan of establishing the Union Government was unanimously endorsed 
during the AU Accra Summit in mid-2007 (African Union 2007), even though most governments factually refused the implementation of this declaration. The first loophole African leaders saw, was to refer the matter to a committee (African Union 2007), and later on to point to an infringement of the Constitutive Act with the declaration on the United States of Africa (African Union 2009). The AU Commission subsequently suggested that instead of forming the Union Government, the AU Commission should be transformed into an AU Authority with more power than the Commission (African Union 2009). The debate provoked by this proposal became wedged in the question of whether the $A U$ Constitutive Act had to be amended for the realisation of the AU Authority. With Gaddafi leaving the AU chair in 2010, and with his death in mid-2011, the debate effectively stopped, and only very few people in the member states and the AU regret the abandoning of the plan. ${ }^{3)}$

One might wonder why AU member states have endorsed the Accra Declaration initially even though they are in fact against it. With reference to Mauritius, an observer noted that the island state supported the declaration only "because there's no immediate danger of it happening. And there's really no opportunity cost in terms of supporting it at a theoretical level, while it's still so far down the track, whereas there may be some immediate opportunity costs in [...] being seen to vociferously oppose it". ${ }^{4}$ ) This plausible explanation can certainly be applied to several AU members, particularly smaller and less influential states, including those who had been receiving financial aid from Libya.

With regard to unconstitutional change of government, the $A U$ has adopted a strict policy and automatically suspends the effected member state from the organisation. While this is seen as an achievement, there remain some AU member states governed by leaders who seized power through unconstitutional means but are not criticised by the $\mathrm{AU}$ for this. Moreover, there are different approaches between regional economic communities and the $\mathrm{AU}$ in their dealings with unconstitutional change of government. Unlike in the case of Mali, where the Economic Community of West African States (ECOWAS) also suspended Mali from its organisation after a coup d'état as the AU had done, the coup in the Central African Republic in March 2013 resulted in no suspension of the country from the Economic Community of Central African States (ECCAS). In fact, ECCAS - and most notably Chad - did little to prevent the coup (see Meyer 2013). Regional 
leaders ignored the AU's move to suspend the country and worked closely with the new leadership, leaving bad blood between the $A U$ and ECCAS.

The South African Business Day pointed to another inconsistency with regard to the AU's dealing with crisis situations when it asked more than a decade ago: "while it [the AU] may involve itself in the affairs of a sovereign state in the instance of genocide and gross violations of human rights, how will it handle a country whose policies amount to incremental genocide and which have a negative effect on the economies, and indeed the political stability, of neighbouring states?" (Business Day, 12 July 2002). Examples of the AU's reluctance to engage in crisis solution include Togo, which saw violence and a mass flight following the disputed elections in 2005; Guinea, where the military junta massacred more than 150 people in September 2009; and Kenya, where widespread violence erupted after the disputed elections in December 2008. More recent cases include the early phase of the crisis in Côte d'Ivoire in 2010/11, as well as the crises in Tunisia and Egypt (2010/11), when the AU failed to take a firm stance against political violence and only passed decisions once the leaders had already stepped down (African Union Peace and Security Council 2011b; African Union Peace and Security Council 2011c). The AU was also slow in reacting to the Mali crisis (2012/13), where it was outpaced by France and the United Nations (UN) (Weiss and Welz 2014).

On the other hand, the AU is widely respected for what it has achieved in war-torn Somalia. While the rest of the international community stands on the sidelines - following the American trauma of 1993 - the AU has notably improved the security situation through its fight against the al-Shabab. The Comoros and Burundi interventions also resulted in some success for the AU, as does the UN-AU hybrid operation in Darfur. It is too early to judge the ongoing AU operation in the Central African Republic, but what is clear is that the AU proved itself once more as a risk-assuming actor that tries to work on its image as potent security provider.

Generally speaking, we can observe some advancement, yet at the same time we see persistence in the status quo. 'Consistency' and 'earnestness' cannot necessarily be considered as the hallmarks of the $\mathrm{AU}$, despite the Commission's attempts. AU member states endorse certain policies but in reality do not implement or even oppose them. For instance, the Chadian government pushes hard to decrease the 
AU's political leadership of a crisis solution in the Central African Republic and instead aims to install ECCAS - under Chad's leadership - as the prime institution to address the crisis. Similar moves have been undertaken by the members of ECOWAS during the Mali crisis and Southern African countries with regard to the crises in Madagascar and Zimbabwe. These are signs that a large number of African leaders rather want the regional economic communities to be in control of crisis solution, also because they have a tighter control over these organisations.

\section{Reasons for the 'culture of conservatism'}

Four reasons that might explain the 'culture of conservatism' are elaborated in this section. These are lack of capacity, lack of willingness to cede sovereignty, national leaders' refusal to surrender personal power, and the fact that regional economic communities might be more attractive - and controllable - for member states. This is not an allinclusive list. There are many other explanations that come into play, such as economic reasoning or the legacies of the independence struggle, as reflected upon elsewhere (Welz 2012).

Firstly, with regard to the lack of capacity, we see a large number of African states not having the resources to engage in continental or regional integration. The reasons are various and include a lack of finances or the fact that there are vital domestic problems - such as post-conflict reconstruction - to solve. States suffering from a civil war, being in a post-conflict situation, or experiencing a coup d'état might have no resources for visionary ideas like continental integration that offer little direct and immediate benefits. The case of Burundi, suggests that the foreign policy focus of a post-conflict state is on the donor countries that assist the recovery of such states (see Bauer and Langen 2007). The region only comes second, let alone the continental level. The same is true for Libya or Mali, which turn towards Europe and France in particular - as they see more benefits and aid during their post-conflict phases coming from across the Mediterranean than from the AU.

Numerous AU member states depend on donor aid and do not have the ability to generate the necessary funds to finance state administration or state provided infrastructure such as schools or roads. This lack of financial resources resonates with their inability to engage 
in continental affairs (Gottschalk and Schmidt 2004: 138-158). Three examples highlight the problem: First, many states struggle to afford tickets for their PAP members to fly to the plenary sessions. Even the authorities of Mauritius, one of the richest AU members, claim that they face severe financial restraints and cannot send their PAP members to the entire session. ${ }^{6}$ Secondly, some member states have no right to vote in the AU as they have not paid their fees. Liberia's President Johnson-Sirleaf, for example, was denied the opportunity to speak at the AU summit in Banjul in 2006 due to this (Loetzner 2007: 227). Lastly, the need to 're-hat' AU missions to be superseded by UN missions is to a large extent due to a lack of $A U$ funding. The bulk of funding for $\mathrm{AU}$ missions does not come from the AU members or the $A U$ itself - its peacekeeping fund reportedly amounts to a mere US\$2 million $^{7)}$ — but mainly from Western donors. During the Mali crisis the presidents of Guinea, Niger and Senegal pressured France to act because outside assistance and resources were needed. The AU remains dependent on key African states, as Ethiopia's involvement in the Somali crisis and South Africa's engagement in Burundi suggest. It is thus all the more surprising that $A U$ member states could not agree on a financing mechanism proposing to raise a small fee on flight tickets within the continent and a marginally greater one on intercontinental flights into Africa.

Secondly, perhaps even the biggest stumbling block for deeper integration is the lack of willingness of African states to cede sovereignty vis-à-vis the AU (Schmidt 2005; Sturman 2007; Makinda and Okumu 2008). Clapham noted more than a decade ago that, "postcolonial states have, since their independence in the decades following the Second World War, emerged as the most strident defenders of Westphalian sovereignty in the international order" (Clapham 1999: 100). It is true that sovereignty played a prominent role during the founding period of the OAU when African leaders opted to guard their recently won sovereignty after decades of foreign rule (van Walraven 2010: 31-56). Instead of building the United States of Africa as promoted by Nkrumah (1963), Africa's leadership decided to establish a loose alliance of African states when they founded the OAU with respect of sovereignty as one of the organisation's main principles. During its existence, the OAU did not seriously and sustainably challenge this principle and also adhered to a doctrine of non-interference (Welz 2013).

Sovereignty continues to play a determining role in the current 
debate on political integration on the continent (Gans 2006; Kambudzi 2008). In the context of the Grand Debate, for instance, the member states decided to establish a ministerial committee to explore new avenues for the Union Government. The mandate of the committee was inter alia the "identification of domains of competence and the impact of the establishment of the Union Government on the sovereignty of member states" (African Union 2007, Accra Declaration, emphasis added), indicating that the sovereignty question was part of the member states' reasoning. In fact, several documents on the Union Government and related issues stress that the sovereignty of the AU member states must remain intact. The way the Union Government will function if there is no sign that subordinated countries are willing to give up parts of their sovereignty remains unclear.

Research on Algeria, Ethiopia, Swaziland and Zimbabwe, for example, reveals that the principles of non-interference and sovereignty are still considered important if not sacrosanct (Welz 2012). In Algeria, the elite that fought against French oppression in the 1950s and achieved independence guards its sovereignty strictly (Akacem 2004: 153-168; APRM 2007b). In Ethiopia, a long-standing tradition and pride that dates back to the Aksumite empire more than 2000 years ago, and the fact that Ethiopia is the only African state that has never been colonised, make it almost unimaginable for Ethiopia's leadership to cede sovereignty. Swaziland's king made it clear that "no one tells Mswati what to do" (Matlosa 1998: 333), and Zimbabwe's President Robert Mugabe said in the context of the presidential elections in 2008 that "[n]o country in the world, including those in the African Union and SADC can dictate how Zimbabwe should conduct its elections", and even went further to threaten that the "irresponsible and reckless statements by some SADC leaders could lead to the breaking up of the regional grouping" (The Herald, 27 June 2008). Although one should not generalise from four cases, there is little doubt that similar resistance to cede sovereignty and to engage in the building of a strong continental organisation can be found in other AU members states.

However, whereas sovereignty was absolute in the OAU, the principle was legally undermined with the establishment of the AU as shown above. Thus a mixed picture emerges: Despite the right of the AU to intervene in other states' internal affairs in specified circumstances, it is also true that the protection of sovereignty still remains a guiding principle in the AU as found in Article 3(b) of its Constitutive Act 
(African Union 2000). This tension between strict adherence to the sovereignty principle and collective responsibility is reflected in the way the AU currently operates. While the AU member states - represented in the Assembly and Peace and Security Council - want to maintain their influence and control, the AU Commission often pushes ahead, sets the agenda, and tries to convince member states to follow its lead. The vast number of decisions adopted by the Peace and Security Council, for instance, were initiated by the AU Commission, specifically by the Department of Peace and Security, and not by the member states. In other words, we can observe a tendency to erode the AU member states' predominance that might result in a slow undermining of member states' sovereignty.

Thirdly, the sovereignty question goes hand in hand with the personalisation of power in many African countries. Even though there is a growing number of African leaders that leave office after having lost elections or when a constitutional term limit does not allow for a reelection (for example, Ghana, Mauritius, Namibia, Senegal, South Africa, or Zambia), there are also several African leaders that amended their constitution to allow for re-election despite earlier term-limits (for example, Algeria, Burkina Faso, and Uganda) or try to stay in power by using coercive means as the events in Côte d'Ivoire in 2011 suggest. The personalisation of power is part of the reason for the image of the OAU as a 'Club of Dictators' and the AU should carefully watch that it will not be depicted similarly.

Lastly, regional economic communities are often considered more attractive for African states than the continental integration project. This becomes apparent for instance in Burkina Faso, which champions ECOWAS. The landlocked country in West Africa conducts 26.5 per cent of its trade within the ECOWAS region (calculated with figures in Cernicky 2008). This large figure reveals that it uses the regional grouping for economic purposes. But it also aims to intensify political integration, including free movement of people within the community and the use of a common passport. The same is true for Uganda, where President Yoweri Museveni is a strong supporter of fast-tracking regional integration in the context of the East African Community (EAC) (Braude 2008, Welz 2013a). Similarly, Mauritius shows sympathy with the Southern African Development Community (SADC) project and hopes that the community will develop further so that trade is intensified in the region, which in turn will support Mauritius' economy. Al- 
though South Africa is economically strong enough that it does not necessarily need the SADC or the AU, as the bigger part of its exports go to the European Union (27.0 per cent) and China (13.5 per cent), the SADC is nevertheless important for its exports, as 11.6 per cent go there, while only 4.4 per cent of South Africa's exports are to parts of Africa beyond the SADC region (calculated with figures provided by the Department of Trade and Industry 2010). This shows the relative importance of South Africa's immediate region for trade compared to the continent. The SADC region hence gets more attention than the AU despite some attempts of South Africa to move beyond the region, as its recent involvement in the crisis in the Central African Republic suggests. Under President Zuma foreign policy is inspired by pragmatism and designed to support national (economic) interests (Economist 14 October 2010). Lastly, in the case of Swaziland, South Africa's hidden subsidies through the Southern African Customs Union (SACU), equalling two-thirds of Swaziland's national revenue (at least until 2010 when the SACU revenues collapsed due to the global financial and economic crisis), are an argument for Swaziland to reject a deeper economic and political integration on the continental level, because the biggest part of the national revenue is at stake if a free trade area were to be established on the continental level. In short: the cases show that the regional economic communities are more beneficial than the $\mathrm{AU}$ in economic terms, and a consequence of this is that states focus on these regional organisations and give them priority.

Political considerations also play a role. As pointed out above, states have an interest to keep control over crisis solution within their region. ECOWAS has done that with regard to Mali, ECCAS attempts it with regard to the Central African Republic, and SADC's involvement in the crises of Madagascar and Zimbabwe point in the same direction. National and regional interests are at stake and national leaders often see their regional economic community better suited to address crises. If the Zimbabwe crisis, for instance, had been referred to the $A U$ instead of remaining in the hands of SADC, South Africa would certainly have lost some of its control over the process. We have to regard the current debate on the establishment of the African Capacity for Immediate Response, a rapid reaction force, as either a temporary or permanent substitute to the Regional Stand-by Brigades in this light. If the plan of establishing regional brigades will be abandoned in favour of a rapid reaction force, the regions will lose considerable influ- 
ence. Hence it comes as no surprise that most of them are adamant that the African Capacity for Immediate Response will become a temporary substitute at best, but not a permanent institution.

\section{Conclusion}

This overview has shown the limited interest of African states and their leaders to alter the status quo with regard to the continental political integration project and that a 'culture of conservatism' prevails. It has also highlighted a gap between the $A U$ and its member states and that vision outpaces reality. Only if the AU and its member states are able to close the gap among them by managing to transform the AU into an actor that reflects, articulates, and implements collective decisions of the member states, does the AU have a chance to succeed. So far earnestness and coherence is often missing. The gap between the member states and the AU often results in inconsistent policies that derogate the achievements that have been made.

The AU must make an attractive offer to its member states to ultimately achieve peace, security and stability on the continent as a basis on which political and economic development can take place. At the same time, the AU must support an African-grown democratisation process. Progress in the peace and security realm and in its democratisation efforts would make the $A U$ attractive both on the continent and beyond as a partner of other global players, and hence might close the rift between the $\mathrm{AU}$ and its member states, as well as overcome the 'culture of conservatism'.

\section{Endnotes}

1. The establishment of the stand-by brigades is behind schedule. Recent plans focus on the establishment of an African Capacity for Immediate Response to Crises, a rapid reaction force of voluntary participating states, either as temporary or permanent alternative to the stand-by brigades.

2. Interview with a senior AU official, Addis Ababa, March 2010.

3. Interviews with AU officials in Addis Ababa, 2010 and 2014 and with decision makers in various African countries 2009-2013.

4. Interview with a western diplomat in southern Africa 2009.

5. Interviews with AU and other officials, Addis Ababa, February 2014.

6. Interviews with members of the Pan-African Parliament in Mauritius, 
November 2009.

7. Interview with an AU official, Addis Ababa, February 2014.

\section{Bibliography}

Africa Research Bulletin (2001), May 1st-31st 2001, p 14407 A-C.

African Union (2000), Constitutive Act of the African Union. Lomé, 11 July 2000.

African Union (2007), Accra Declaration, Assembly/AU/Decl.1-2(IX), Accra, 1-3 July 2007.

African Union (2008), Report of the First Meeting of the Committee of Twelve Heads of State and Government of the Union Government, Assembly of the African Union Report, Assembly/AU/11/(XI), Arusha, 2008.

African Union Executive Council (2008), Report of the Ministerial Committee on the Union Government. Executive Council Twelfth Ordinary Session, EX.CL/390 (XII)-b (Annex), Addis Ababa, 25-29 January 2008.

African Union (2009). Decision on the Special Session of the Assembly on the Union Government, Assembly/AU/Dec.233(XII), Addis Ababa, 1-3 February 2009.

African Union (2011), Press Release: "The African Union Ad Hoc High-Level Committee on Libya Meets in Nouakchott on 19 March 2011", Addis Ababa, 17 March 2011.

African Union Peace and Security Council (2011). Communiqué of the 261st Meeting of the Peace and Security Council on the Situation in Libya, PSC/ PR/COMM(CCLXI), Addis Ababa, 23 February 2011.

African Union Peace and Security Council (2011b). Communiqué of the 260th Meeting PSC/PR/COMM.(CCLX), Addis Ababa, 16 February 2011.

African Union Peace and Security Council (2011c). Communiqué of the 257th Meeting, PSC/PR/COMM.2(CCLVII), Addis Ababa, 15 January 2011.

Akacem, M (2004), "The Role of External Actors in Algeria's Transition", Journal of North African Studies, Vol 9, No 2, pp 153-168.

Akokpari, J (2008), "Dilemmas of Regional Integration and Development in Africa", in Akokpari, J, Ndinga-Muvumba, A, and T Murithi (eds), The African Union and its Institutions. Auckland Park: Fanele, pp 85-112.

Ankomah, B (2007), "African Union: From Non-Interference to Non-Indifference", New African, No 460, pp 10-12.

APRM (2007), APRM Country Report No. 4: South Africa. Midrand: APRM Secretariat.

APRM (2007b). APRM Country Report No. 5: Algeria. Midrand: APRM Secretariat.

APRM (2009), APRM Country Report No. 9 of Burkina Faso. Midrand: APRM 
Secretariat.

APRM (2009b), APRM Country Report No. 7 Republic of Uganda. Midrand: APRM Secretariat.

APRM Monitor (2006), APRM in South Africa: What Will the Final Report Say?, No 2.

Bauer, S and M Langen (2007), "Burundi", in Gieler, W (ed), Die Außenpolitik der Staaten Afrikas: Ein Handbuch: Ägypten bis Zentralafrikanische Republik. Paderborn: Schöningh, pp 89-95.

BBC News (2009), "Ethiopia imposes Aid Agency Curbs". (Available at: http:// news.bbc.co.uk/2/hi/7814145.stm, accessed on 15 March 2010.)

Boumghar, M (2009), The APRM in Algeria: A Critical Assessment. Johannesburg: African Governance Monitoring and Advocacy Project.

Braude, W (2008), Regional Integration in Africa: Lessons from the East African Community. Johannesburg: South African Institute of International Affairs.

Business Day (2002a), "AU Can Fulfil Pan Africanists' Dream", 16 August 2002. Business Day (2002b), "AU's Morning After", 12 July 2002.

Cernicky, J (2008), Regionale Integration in West Africa: Eine Analyse der Funktionsweise von ECOWAS und UEMOA. Bonn: Scientia Bonnensis.

Cilliers, J (2003), "From Durban to Maputo: A Review of 2003 Summit of the African Union", ISS Paper 76.

Cilliers, J and P Mashele (2004), "The Pan-African Parliament. A Plenary of Parliamentarians", African Security Review, Vol 13, No 4, pp 73-82.

Clapham, C (1999), "Sovereignty and the Third World State", in Jackson, R (ed), Sovereignty at the Millennium. Malden: Blackwell, pp 100-116.

Department of Trade and Industry (2010), "South African Trade by Regions". (Available at: http://www.dti.gov.za/econdb/raportt/rapregi.html, assessed on 17 February 2011.)

Economic Commission for Africa (2010). "ECA in the APRM: ECA's Role". (Available at: http://www.uneca.org/aprm/ECAs Role.asp, accessed on 17 April 2010.)

Engel, U and J Gomes Porto (2010), Africa's New Peace and Security Architecture. Farmham: Ashgate.

European Union (2010), European Union Election Observation Mission to Ethiopia 2010: House of Peoples' Representatives and State Council Elections. (Available at: http://www.eueom.eu/files/pressreleases/english/ eueom-ethiopia-fact-sheet-offindings-08112010_en.pdf, accessed on 1 December 2010.)

Franke, B (2009), Security Cooperation in Africa: A Reappraisal. Boulder: First Forum Press.

Franke, B (2010), "Steady but Uneven Progress: The Operationalization of the African Standby Force", in Besada, H (ed), Crafting an African Security 
Architecture: Addressing Regional Peace and Conflict in the 21st Century. Farnham: Ashgate, pp 179-200.

Freedom House Index (2008), (Available at: http://www.freedomhouse.org/ template.cfm?page $=363 \&$ year $=2008$, accessed on 8 May 2009.)

Gans, C (2006), Die ECOWAS: Wirtschaftsintegration in West Afrika. Berlin: Lit Verlag.

Gottschalk, K and S Schmidt (2004), "The African Union and the New Partnership for Africa's Development: Strong Institutions for Weak States?", Internationale Politik und Gesellschaft, Vol 4, pp 138-158.

Herbert, R and S Gruzd (2008), The African Peer Review Mechanism: Lessons from the Pioneers. Johannesburg: The South African Institute of International Affairs, p 264 and pp 243-254.

Herbst, J (2000), States and Power in Africa: Comparative Lessons in Authority and Control. Princeton: Princeton University Press.

Jordaan, E (2006), "Inadequately Self-Critical: Rwanda's Self-Assessment for the African Peer Review Mechanism", African Affairs, Vol 105, No 420, pp 333-351.

Kambudzi, A M (2008), "Portrayal of a possible Path to a Single Government for Africa", in Murithi, T (ed), Towards a Union Government for Africa. Pretoria: Institute for Security Studies, pp 13-28.

Mail and Guardian (2007), "Which Peers will Mbeki Listen to?", 1 February 2007.

Makinda, S and F Wafula Okumu (2008), The African Union: Challenges of Globalisation, Security, and Governance. Abingdon: Routledge.

Masterson, G (2005), "An Analysis of the Implementation of the African Peer Review Mechanism in Ghana, Kenya and Mauritius", EISA: Occasional Paper, No 29.

Matlosa, K (1998), "Democracy and Conflict in Post-Apartheid Southern Africa: Dilemmas of Social Change in Small States", International Affairs, Vol 74, No 2, pp 319-337.

Meyer, A (2013), "10 Years of Regional Security Cooperation in the Central African Republic - and still no Stabilization in Sight?", Paper presented at the European Conference on African Studies, Lisbon, 26-28 June 2013. (Available at: http://uww.nomadit.co.uk/ecas/ecas2013/panels.php5?PanelID=2110, accessed 6 February 2014.)

Murithi, T (2005), The African Union: Pan-Africanism, Peacebuilding and Development. Alderhot: Ashgate, Alderhot.

Mwanasali, M (2009), "From Non-Interference to Non-Indifference: The Emerging Doctrine of Conflict Prevention in Africa" in Akokpari, J, Ndinga-Muvumba, A and T Murithi (eds), The African Union and its Institutions. Auckland Park: Fanele, pp 41-62.

Natielsé, J K (2009), The APRM Process in Burkina Faso. Johannesburg: 
African Governance Monitoring and Advocacy Project.

Nkrumah, K (1963), Africa Must Unite. New York: Frederic Praeger Publishers. Olivier, G (2003), "Is Thabo Mbeki Africa's Saviour?", International Affairs, Vol 79, No 4, pp 815-828.

Organisation of African Unity (1963), OAU Charter. Addis Ababa, 25 May 1963. Organisation of African Unity (2001), Protocol To The Treaty Establishing the African Economic Community Relating To The Pan-African Parliament. Adopted by the 5th Extraordinary Session of the Conference of Heads of State and Government, 2 March 2001, Sirte.

Packer, C and D Rukare (2002), "The New African Union and Its Constitutive Act", The American Journal of International Law, Vol 96, No 2, pp 365-379.

Pan-African Parliament (2007), "La Contribution du Parlement Panafricain au Grand Débat dont le Thème est: 'Le Gouvernement D'Union"', Presented at the 9th AU Summit, Accra, 1-3 July 2007, PAP/P.7MP/52/7.

Pan-African Parliament (2010), "Debates of the Pan-African Parliament Volume 3", Midrand, 6 October 2010.

Pan-African Parliament Election Observer Mission (2007), "Statement of the Pan -African Parliament Election Observer Mission to Kenya's General Election Held on 27th December 2007".

Pan-African Parliament Election Observer Mission (2008), "Report of the PanAfrican Parliament Election Observer Mission: Presidential Run-Off Election and House of Assembly By-Elections, Republic of Zimbabwe, June 27, 2008, PAP/S/RPT/76/08.

Reporters Without Borders (2010), Press Freedom Index 2010.

Schmidt, S (2005), "Prinzipien, Ziele und Institutionen der Afrikanischen Union", Aus Politik und Zeitgeschichte, 4/2005, pp 25-32.

South African Institute of International Affairs (2006), "Comparison of South African APRM Country Self-Assessment". (Available at: http:// www.saiia.org.za/images/upload/SA-APRM_Comparison.pdf, accessed 22 January 2010).

Sparks, D L (2009), "Swaziland: Economy", in Frame, I (ed), Africa South of the Sahara, 38th ed. London: Routledge, pp 1156-1161.

Sturman, K (2007), "New Growth and Deep Roots: Prospects for an African Union Government", ISS Paper 146.

Sunday Times (2006), "Africa tells SA to fight Crime", 3 December 2006.

The Herald (2008), "Mugabe Turn to African Nations", 27 June 2008.

Tronvoll, K (2009), "Ambiguous Elections: The Influence of Non-Electoral Politics in Ethiopian Democratisation", Journal of Modern African Studies, Vol 4, No 73, pp 449-474.

Van Walraven, K (2010), "Heritage and Transformation: From the Organization of 
African Unity to the African Union", Engel, U and J Gomes Porto (eds), Africa's New Peace and Security Architecture: Promoting Norms, Institutionalizing Solutions. Farnham: Ashgate, pp 31-56.

Weiss, T G and M Welz (2014, forthcoming), "The UN and AU in Mali and Beyond: A Shotgun Wedding?", International Affairs, Vol 90, July.

Welz, M (2013), "From Non-Interference towards Non-Indifference: The Ongoing Paradigm Shift in the African Union", in Engel, $U$ and J Gomes Porto (eds), Towards an African Peace and Security Regime: Continental Embeddedness, Transnational Linkages, Strategic Relevance. Farnham: Ashgate, pp 31-52.

Welz, M (2013a), "Uganda and the East African Community: Economic Imperatives, President Museveni, and His Ambitions", in Lorenz, $U$ and $M$ Rempe (eds), Mapping Agency: Comparing Regionalisms in Africa. Farnham: Ashgate, pp 97-111.

Welz, M (2012), Integrating Africa: Decolonization's Legacies, Sovereignty and the African Union. London: Routledge.

Williams, P D. (2007), "From Non-Intervention to Non-Indifference: the Origins and Development of the African Union's Security Culture", African Affairs, Vol 106, No 423, pp 253-279. 